\title{
The Reaction of Russian Public Companies' Stock Prices to Sanctions Against Russia
}

\author{
Julia Naidenova, \\ Junior Research Fellow at International Laboratory of Intangible-driven Economy \\ National Research University Higher School of Economics \\ 27, Lebedeva street, 614107 Perm, Russian Federation \\ E-mail: yunaydenova@hse.ru
}

Anastasia Novikova ,

E-mail: Ana.K.Novikova@gmail.com

\begin{abstract}
The imposition of sanctions by foreign countries against Russia since 2014 and their prolongation for the following several years resulted in significant changes in Russian economics. In the first instance, economic sanctions were aimed towards the weakening of companies by banning exports and imports of certain goods, closeout or suspension of joint venture projects, as well as limiting the provision of financing. However, one can postulate that these sanctions influenced the companies to different extents. This research offers an analysis of the changes in share prices of Russian public companies of the MICEX index in response to sanctions against Russia in 2014-2016. The research methodology is based on the event study approach, which allows estimation of a short-term response of the shares' prices to information release. The results of this paper confirm that imposition and prolongation of sanctions resulted in a significant fall in share prices. With an average daily return on shares of the Russian stock market companies of $0.1 \%$, a fall in return of $0.17 \%$ points per day as a result of the imposition of sanctions by the USA is economically significant. Apart from that, the sanctions influenced financially dependent companies to a greater extent. Contrary to theoretical assumptions of a greater influence of sanctions imposed by the countries with which a more close economic cooperation had been established, it transpired that the imposition of sanctions by the USA resulted in the greatest fall in prices for shares. Also, an important result indicated in this paper is the fact that imposition of targeted sanctions against certain companies has not entailed a greater impact of the sanctions on such companies. This is indicative of the ineffectiveness of targeted sanctions imposed on Russia. The influence of the government share in ownership of companies and the differences of response of the shares' prices depending on the company industry sector have not been confirmed.
\end{abstract}

Keywords: sanctions; Russia; stock market; public companies; event study; abnormal return JEL: G14, F51, G30

The research has been funded by a grant of the Russian Science Foundation under the scope of project No. 18-18-00270. 


\section{Introduction}

In March of 2014, in spite of warnings by the USA of possible grave negative implications Russia recognized the results of the referendum concerning Crimea joining Russia. In retaliation, the USA, European Union (EU) and a series of countries imposed sanctions against certain natural and legal persons of the Russian Federation. The sanctions demonstrated disagreement on the Russian policy as regards Crimea and were positioned as a tool of pressure upon Russia in order to reconcile the conflict and to protect territorial integrity of Ukraine. Later escalation of conflict in Ukraine triggered prolongation of sanctions and imposition of new sanctions as well as other countries' joining the policy of imposition of limitations against Russia.

The sanctions comprise such economic limitations as restricted access to financial resources, the freezing of assets, the termination of business relationships and the banning of imports and exports of certain goods. Apart from that, sanctions against Russia vary by scale: aside from comprehensive sanctions, also targeted sanctions against certain persons and organizations were imposed. However, the degree of their impact remains questionable because apart from an evident detrimental effect sanctions resulted in decrease of competition for Russian companies in the domestic market and thus in promotion of their development.

Certainly, economic sanctions against Russia carry longterm economic consequences and it is necessary to evaluate in their entirety the overall economic losses caused by their imposition. However, using the stock market data as an indicator of the economic situation, one can evaluate changes in investors' expectations because of information about sanctions. Consequently, the purpose of the present research is evaluation of the impact of sanctions against Russia on the price of shares of Russian public companies in the short term. This will help us to define which companies suffered to a greater extent from the imposition of sanctions and need government support, and also to reveal the features of the companies which helped to mitigate the impact of foreign limitations.

\section{Review of Literature}

\section{Sanctions in international practice and their effectiveness}

The term "sanctions" has no unified agreed-upon definition; in the legislation of each country it tends to have its own definition. Thus, in accordance with the legislation of the Russian Federation, economic sanctions are defined by the Federal Law "On Special Economic Measures" No. 281-FZ of December 30, 2006 as "special economic measures" which "are applied in cases of a set of circumstances which require an urgent response to an internationally wrongful act or a hostile act of a foreign state or its authorities and officials which threaten interests and security of the Russian Federation and (or) acts violating rights and liberties of its citizens and in accordance with the resolutions of the Security Council of the United Nations Organization". Researchers give different definitions of economic sanctions but in general they are understood as "restrictive or prohibitive economic measures" [Davis, Engerman, 2003]. From a theoretical point of view, the purpose of sanctions is to put pressure on a country in order to make it change its policy, to restrict a country's actions and (or) send a certain message [Giumelli, Ivan, 2013; Veebel, Markus, 2015].

Sanctions are a rather widespread practice in foreign relations because they may be considered as a means of influencing which is less radical and less harmful for all parties in comparison to military operations [Pape, 1997]. Thus, for example, the EU has a regularly updated document entitled "EU Restrictive Measures in Force" which contains a list of more than 30 countries as of 2017 and a list of economic restrictions applied against those countries. The most discussed sanctions on a top-level as well as by academic community are the sanctions against Iran [Carswell, 1981; Torbat, 2005; Esfandiary, Fitzpatrick, 2011; Fayazmanesh, 2003; Kozhanov, 2011; O’Sullivan, 2010; Patterson, 2013; Kozhanov, 2011].

In the majority of cases analysis of the economic repercussions of sanctions is of a descriptive nature which does not separate sanctions effects from other factors. So, researchers marked such sanctions' consequences variously as a significant drop in the exchange rate of the domestic currency in Iran [Amuzegar, 1997], a rise in the inflation and unemployment rate in Libya [Collins, 2004], and a decline in economic activity in Haiti [Gibbons and Garfield, 1999].

Previous theoretical and empirical papers presume that the power of impact of sanctions depends on many factors but, first of all, on the nature of imposed restrictions and correlation of strength of the country imposing sanctions and the country against which they are used. Researchers make a point that the smaller the country is, the less severe sanctions suffice to make it change its conduct. And, vice versa, large and self-sufficient countries resist sanctions easier than small ones [Kaempfer, Lowenberg, 2007; Jing, Kaempfer, Lowenberg, 2003]. Another factor distinguished by researchers as an indicator of sanctions' impact power is the strength of relationship between the country imposing sanctions and the country against which they are used [Jing, Kaempfer, Lowenberg, 2003; Pape, 1997]. It is affirmed that the stronger trade and economic relations between the two countries are the more significant the effect of sanctions imposed by one of them. Besides, presumably sanctions should be more effective if there is a strong inequality in distribution of incomes of the country's citizens [Pape, 1997]. Apart from that, Pape [1997] argues that the effect of economic sanctions may be strengthened if they are combined with military force. The effectiveness of economic sanctions as an international public policy tool is also a widely discussed issue. On the basis of an analysis of over one hundred cases it is clear that only in one third of cases the aim of sanctions 
was achieved [Hufbauer, Schott, Elliott, 1990; Klinova, Sidorova, 2016]. Pape also showed that by no means in all cases a significant contraction of the economy was registered in the country against which sanctions had been imposed [Pape, 1997, 1998]. So, the author presumes that if a problem concerns territory, safety, welfare or the political regime of a country, the sanctions will be ineffective. Veebel and Markus [Veebel, Markus, 2015] analyzed the ostensible purposes of the EU's sanctions against Russia and Russia's retaliatory measures and came to the conclusion of a low probability of the sanctions' success due to absence of a well-defined objective and insufficient political measures.

\section{Research on sanctions against Russia}

Analyses of the consequences of sanctions against Russia are studied extensively by researchers from a wide variety of perspectives: description of the history of the development of the underlying conflicts and changes in the economy [Veebel, Markus, 2015], a study of the crisis as one of the factors that impeded the country's economic growth with respect to the forecasting of potential changes in macroeconomic indicators [Gurvich, Prilepskiy, 2015; Akidinova, Yasin, 2015], the influence on consumers [Nureev, Petrakov, 2015], and revealing the spheres of the biggest impact of sanctions [Portansky, 2014; Golikova, Kuznetsov, 2017]. All this demonstrates multidimensionality of influence exerted by sanctions on the Russian economy.

Other studies have focused on conclusions about the companies themselves. The research by Gurvich and Prilepsky [2015] shows that by 2017 sanctions had already exerted a considerable influence on the real sector of economy and resulted in a significant capital outflow from the country and GDP decrease approximately by $6 \%$ in comparison to 2013. Fomicheva [2016] points to the fact that after imposing sanctions against Russia, credit rating agencies downgraded the country's credit rating, thus further decreasing the attractiveness of Russian companies for foreign investors. Klinova and Sidorova [2016] make an assumption that sanctions will primarily influence the high-tech and financial sectors of the economy because for them cooperation between Russia and the EU is of most importance. Golikova and Kuznetsov [2017], on the basis of a survey of employees from Russian manufacturing companies, presume that the increased integration of Russian companies into the global economy will result in more severe consequences of sanctions. Similarly, the large, successful companies carrying on business in the global market will also suffer the biggest losses. Hoffmann and Neuenkirch [2017] showed that the development of the conflict in Ukraine resulted in Russian stock market disruptions.

Among positive fallouts of sanctions the researchers point out the growth of "economic patriotism" in Russia. The influence of sanctions on agriculture is ambivalent: on the one hand, decrease of competition with foreign companies should incentivize an imports substitution process, on the other hand, restrictions of imports of means of production may impede Russian companies trying to develop their potential to the necessary extent and to expand the capacities they need [Klinova, Sidorova, 2016].

Sanctions against Russia are a significant macroeconomic external shock and produce an integrated effect on the economy of the country. That is why it is difficult to evaluate their influence in isolation of other events and also due to rare occurrence of many macroeconomic indicators. Thus, for example, Gurvich and Prilepskiy [Gurvich, Prilepskiy, 2015] point out that the Russian economy shrinking was related to a sharp decline of oil price and Russian companies managed to adjust to conditions created by sanctions due to transfer to a floating exchange rate. All the above emphasizes the complexity of analyses dedicated to sanctions influence on the Russian economy.

\section{Research Problem}

In this research we used the event study method based upon an assumption of stock market effectiveness and helping to evaluate the influence of a certain event on the price of shares [MacKinlay, 1997; Binder, 1998]. This method may be used to analyze corporate and macroeconomic events [MacKinlay, 1997]. For example, it was used to evaluate the influence of political news on the stock market [Guidolin, Ferrara, 2010; Ghanem, Rosvall, 2014]. In our case the 'event' is the instance of a release of information on imposition of sanctions. In this regard the date of first publication of announcement precedes the actual imposition of sanctions, but investors of the stock market take into consideration the information thus changing the shares' price only if there exists grounds for change of expectations. Due to the fact that the event study method uses daily data and the response of investors is evaluated on a short-term basis, it is possible to distinguish the direct influence of sanctions from other factors.

As noted above the event study method is based upon the assumption of the stock market effectiveness. Although the Russian stock market is characterized by a relatively low liquidity and small size, the event study method has been used to analyze it in a series of papers [Teplova, 2008; Yavorskaya, 2013; Pogozheva, 2013; Naidenova, 2015; Yavorskaya, Yavorsky, 2015; Rogova, Guseva, 2016]. Nevertheless, in order to obtain correct results, the selection considered within is comprised of the companies with the shares of the biggest liquidity.

Further, in order to carry out a more detailed analysis of the conditions which have to the largest degree influenced the companies' values, we chose the following potentially significant factors: the sanction content (the country which imposes sanctions and sanction orientation to a certain company) and company characteristics (sector of economy, size, financial independence, degree of state ownership). 


\section{Data}

The announcements used for this research are related to the imposition or prolongation of sanctions against Russia (a summary of announcements is enclosed in the appendix). We chose 40 announcements on sanctions against Russia, 26 of which were imposed by USA, 12 by the European Union, and two pieces of news informing of the imposition of sanctions by EU and USA simultaneously. The data about announcements have been collected using the business resource Factiva.

In order to analyze the response of the companies' shares prices and its determinants we collected data as regards companies. The sample comprises 40 Russian companies listed in the Moscow Stock Exchange, and their shares were included in the MICEX index as of December 17, 2013. Thus, we chose the most liquid shares. Stocks returns were collected for the period of July 1, 2013 to December 31, 2016. All information on the shares' prices was collected in the Finam web site (Finam.ru). The sample structure, as broken down by economic sector, is represented in table 1 .

Data as regards the financial characteristics of companies and ownership structure were collected from the databases Ruslana and Thomson Reuters. The sample comprises 14 companies partially owned by the government, that is $33 \%$ of the total amount. The key characteristics of the companies are presented in table 2.

Table 1. Distribution of the selection companies by sectors

\begin{tabular}{|c|c|c|}
\hline Sector & $\begin{array}{l}\text { Number of } \\
\text { companies }\end{array}$ & Companies \\
\hline Oil and gas & 8 & $\begin{array}{l}\text { PJSC Bashneft, PJSC Gazprom, PJSC Lukoil, PJSC Oil Company } \\
\text { Rosneft, PJSC NOVATEK, PJSC Surgutneftegas, PJSC Tatneft, PJSC JSC } \\
\text { Transneft }\end{array}$ \\
\hline Metals and mining & 8 & $\begin{array}{l}\text { PJSC JSC ALROSA, PJSC MMK, PJSC Novolipetsk Metallurgical } \\
\text { Complex (NLMK), PJSC Mining and Metallurgical Company Norilsk } \\
\text { Nickel, Polymetal International plc, United Company RUSAL plc, PJSC } \\
\text { Severstal, PJSC Corporation VSMPO-AVISMA }\end{array}$ \\
\hline Banks and finance & 5 & $\begin{array}{l}\text { PJSC Bank VTB, PJSC Bank Saint-Petersburg, PJSC Moscow Stock } \\
\text { Exchange, PJSC Sberbank of Russia, PJSC Joint-Stock Financial } \\
\text { Corporation Sistema }\end{array}$ \\
\hline Energy industry & 4 & $\begin{array}{l}\text { PJSC E.ON Russia, PJSC Federal Grid Company of Unified Energy } \\
\text { System, PJSC Inter RAO, PJSC RusHydro }\end{array}$ \\
\hline Telecommunications, IT & 3 & PJSC Megafon, PJSC Mobile TeleSystems, PJSC Rostelecom \\
\hline $\begin{array}{l}\text { Construction and } \\
\text { development }\end{array}$ & 3 & PJSC LSR Group, PJSC MOSTOTREST, PJSC PIK Group of Companies \\
\hline $\begin{array}{l}\text { Consumer goods and } \\
\text { trade }\end{array}$ & 3 & PJSC DIXI Group, PJSC Magnit, PJSC M.video Company \\
\hline Chemical production & 2 & PJSC Uralkali, PJSC PhosAgro \\
\hline Transport & 2 & PJSC Aeroflot, PJSC Novorossiysk Commercial Sea Port \\
\hline Machinery & 2 & PJSC KAMAZ, PJSC SOLLERS \\
\hline
\end{tabular}

Table 2. Characteristics of companies in the selection

\begin{tabular}{|c|c|c|c|c|c|}
\hline Variable & $\begin{array}{c}\text { Number } \\
\text { of observations }\end{array}$ & $\begin{array}{l}\text { Average } \\
\text { value }\end{array}$ & $\begin{array}{l}\text { Standard } \\
\text { deviation }\end{array}$ & $\begin{array}{l}\text { Minimum } \\
\text { value }\end{array}$ & $\begin{array}{c}\text { Maximum } \\
\text { value }\end{array}$ \\
\hline Company size & 40 & 19.690 & 1.300 & 16.867 & 22.058 \\
\hline Financial leverage & 40 & 1.402 & 2.591 & -11.558 & 13.728 \\
\hline Daily stock returns & 34,946 & 0.001 & 0.022 & -0.461 & 0.724 \\
\hline
\end{tabular}




\section{Methodology}

As was already mentioned, the research is based upon the event study methodology. At the first stage we define the abnormal return, i.e. deviation of return from the expected value which is attributed to the event - release of information on imposition of sanctions. At the second stage we define the determinants of the abnormal return.

The abnormal return is calculated as follows:

$A R_{i j t}=R_{i t}-\widehat{R_{i j t}}$,

where $A R_{i j t}$ is abnormal return on a share i for announcement $\mathrm{j}$ for day t; $R_{i t}$ - actual return on a share i for day $\mathrm{t}$; $\widehat{R_{i j t}}-$ normal return on a share $\mathrm{i}$ for announcement $\mathrm{j}$ for day t.

The normal return may be estimated on the basis of various models: constant mean return model, market model, economic models such as CAPM and APT [MacKinlay, 1997; Binder, 1998]. The market model is the most widespread in empirical studies. The market model relates the return of a given security to the return of the market portfolio. Then, based on estimated parameters and the actual return of market portfolio for event day, the normal return is calculated, i.e. the stock return at the date of the event as if the event has not occurred. The equation of normal return is as follows:

$\widehat{R_{i j t}}=\alpha_{i j}+\beta_{i j} \times R_{m t}$,

where $\alpha_{i j}$ and $\beta_{i j}$ are the parameters of the market model; $R_{m t}$ - the return on market portfolio for day $\mathrm{t}$.

In order to take into consideration all the information available to the market to predict the normal return the most relevant stock market index is used. MICEX index is the most relevant index for analysis of shares on the Russian stock market. However, in case of bad macroeconomic events such as imposition of sanctions the whole stock market of the country is sinking. Moreover, the change of sensitivity of company return to systematic risk is possible. Therefore, the market model most probably provides an underestimated absolute value of abnormal return evaluating the drop in the company stock returns against the market downfall in general. Apart from that, the Russian stock market has a small amount of liquid assets and a high concentration of capitalization and its index can be influenced by changes in the share price of large issuers such as Gazprom, Lukoil or Sberbank. Therefore, we used the global index MSCI World as an alternative benchmark. Additionally, we evaluated the abnormal return on the basis of the constant mean return model as follows:

$\overline{R_{i}}=\frac{1}{T} \sum_{t=-200}^{-30} R_{i t}$,

where $\overline{R_{i}}$ is the mean return on a security $\mathrm{i}$; $\mathrm{T}$ is the number of trading days within the estimation window to estimate the normal return model.

The constant mean return model is simple and has low predictive power. However abnormal return calculated using mean return model is not influenced by the change of shares' price when an event occurs and new information for the market is released.

In previous studies the estimation window was chosen rather arbitrarily and varies from 100 to 360 days [Konchitchki, O'Leary, 2011]. For this research we chose an average estimation window of 170 days. In order to prevent the influence of preliminary discussions of possible imposition of sanctions we left an interval of 30 days between the period for estimation of the normal return model and the event date. So, if the date of publishing the announcement about a sanction is denoted as [0], the period of evaluation of the normal return model is $[-200 ;-30]$.

Inasmuch as imposition of sanctions had been discussed previously and that information could have influenced the shares' prices before the official announcement was released, and inasmuch as taking into account of that information by the stock market could take more than one day, we calculated additionally the cumulative abnormal return indicators for three $[-1 ; 1]$ and five $[-2 ; 2]$ days.

The cumulative abnormal return for each announcement was calculated as follows:

$$
C A R_{i j t}=\sum_{t=t 1}^{t 2} A R_{i j t},
$$

where $C A R_{i j t}$ is the cumulative abnormal return on a share $\mathrm{i}$ for announcement $\mathrm{j}$; $\mathrm{t} 1$ and $\mathrm{t} 2$ denote the beginning and end of the event window respectively.

The cumulative average abnormal return shows what was the response to the news on average by the companies:

$$
C A A R_{t 1 ; t 2}=\sum_{t 1}^{t 2} A A R_{t},
$$

where $A A R_{t}=\frac{\sum_{i=1}^{N} A R_{i j t}}{N}$

is an average abnormal return on day $\mathrm{t} ; \mathrm{N}$ is the number of related announcements for the company $i$.

Further, in order to reveal determinants of abnormal return the following model has been tested:

$$
\begin{aligned}
& \text { CAR }_{i j t}=\beta_{0}+\beta_{1} \times \text { sanct_list }_{i j}+\beta_{2} \times U S A_{j}+\beta_{3} \times \\
& \times E U_{-} U_{S A_{j}}+\beta_{4} \times \text { gov }_{i}+\beta_{5} \times \text { raw }_{i}+ \\
& +\beta_{6} \times \text { size }_{i t}+\beta_{7} \times \text { leverage }_{i t}+\text { year }_{t}+\varepsilon_{i j t}
\end{aligned}
$$

where sanct_list $t_{i j}$ is a dummy variable which is equal to one if a sanction $\mathrm{j}$ is targeted against the company $\mathrm{i}$ and zero otherwise. $U S A_{j}, E U_{-} U S A_{j}$ are dummy variables for the countries which impose sanctions - USA and simultaneously USA and the European Union correspondingly; gov $_{i}$ is a dummy variable which indicates whether state own company's shares. Apart from that, we control for the company features: size ${ }_{i t}$ is the company size measured as the natural logarithm of the company market capitalization and leverage $e_{i t}$ is the financial leverage of a company at the end of the previous year. We also allow response of shares' prices to differ due to various 
macroeconomic conditions, accumulation of influence of sanctions on the country economy, retaliation measures and correction of macroeconomic policy. Therefore, we include year effects to the model. $\varepsilon_{i j t}$ is the error term, $\beta$ - the parameters of the model. Indexes $\mathrm{i}, \mathrm{j}$ and $\mathrm{t}$ denote a company, sanctions announcement and time period correspondingly.

\section{Results}

Tables 3-5 show the results of analysis of the average abnormal returns on the basis of eventstudy2 module [Kaspereit, 2016] for statistics package STATA. In case of the market model based on MICEX index (table 3), all tests show a significant positive abnormal return of about $2 \%$ at the second day after the announcement. It means that on average the shares of the companies represented in the sample do not fall as much as the market in whole. Models based on constant mean return and market model estimated using a MSCI World index produce similar results. It is clear from table 4 and 5 that parametric tests (Patell test [Patell, 1976], Boehmer test [Boehmer, Masumeci, Poulsen, 1991], Kolari test [Kolari, Pynnönen, 2010]) show significance almost at all days of the event window while non-parametric tests (Corrado test [Corrado, 1989], Corrado and Zivney test [Corrado, Zivney, 1992], Cowan test [Cowan, 1992]) show a significant negative response only a day before the announcement release. It may be explained by the fact that distribution of abnormal return is close to a normal but leptokurtic, therefore the results of non-parametric tests are more reliable. Existence of response before the announcement release may be explained by the release of information on the planned discussion of sanctions. Consequently, the investors of the Russian stock market estimated the possibility of imposition of sanctions as high enough at the stage of discussion of their potential imposition already.

Table 3. Significance of the average abnormal returns estimated on the basis of the market model with MICEX index

\begin{tabular}{|c|c|c|c|c|c|c|c|c|}
\hline$t$ & $A A R$ & $t$-test & Patell & Boehmer & Kolari & Corrado & Zivney & GenSign \\
\hline-2 & 0.0005 & & & & & & & * \\
\hline-1 & -0.0007 & & $* *$ & & & & & \\
\hline 0 & 0.0003 & & & & & * & * & $* *$ \\
\hline 1 & 0.0001 & & & & & & & \\
\hline 2 & 0.0021 & $* * *$ & $* * *$ & $* * *$ & $* * *$ & $* * *$ & $* * *$ & $* * *$ \\
\hline
\end{tabular}

Note: significant at: ${ }^{*}-10 \% ;^{* *}-5 \% ;^{* *}-1 \%$.

Table 4. Significance of the average abnormal returns estimated on the basis of the market model with MSCI World index

\begin{tabular}{|c|c|c|c|c|c|c|c|c|}
\hline$t$ & $A A R$ & t-test & Patell & Boehmer & Kolari & Corrado & Zivney & GenSign \\
\hline-2 & -0.0018 & $* * *$ & $* * *$ & $* * *$ & & & & * \\
\hline-1 & -0.0053 & $* * *$ & $* * *$ & $* * *$ & * & * & & $* * *$ \\
\hline 0 & -0.0020 & $* * *$ & $* * *$ & $* * *$ & & & & \\
\hline 1 & 0.0028 & $* * *$ & $* * *$ & $* * *$ & & * & & $* * *$ \\
\hline 2 & 0.0016 & $* * *$ & $* * *$ & $* * *$ & & & & $* *$ \\
\hline
\end{tabular}

Note: significant at: ${ }^{*}-10 \% ;{ }^{* *}-5 \% ;{ }^{* *}-1 \%$.

Table 5. Significance of the average abnormal return estimated on the basis of the constant mean return model

\begin{tabular}{|c|c|c|c|c|c|c|c|c|}
\hline$t$ & $A A R$ & $t$-test & Patell & Boehmer & Kolari & Corrado & Zivney & GenSign \\
\hline-2 & -0.0009 & & $* *$ & * & & & & \\
\hline-1 & -0.0062 & $* * *$ & $* * *$ & $* * *$ & $* *$ & * & * & $* * *$ \\
\hline 0 & -0.0024 & $* * *$ & $* * *$ & $* * *$ & & & & \\
\hline 1 & 0.0027 & $* * *$ & $* * *$ & $* * *$ & & & & $* * *$ \\
\hline 2 & 0.0010 & * & $* * *$ & $* *$ & & & & \\
\hline
\end{tabular}

Note: significant at: ${ }^{\star}-10 \% ;^{* *}-5 \% ;^{* *}-1 \%$. 
Table 6. Significance of cumulative average abnormal return estimated on the basis of the market model with MICEX index

\begin{tabular}{|c|c|c|c|c|c|}
\hline$t$ & $C A A R$ & t-test & Corrado_Cowan & Zivney_Cowan & GenSign \\
\hline$[-1 ; 1]$ & -0.0002 & & * & * & * \\
\hline$[-2 ; 2]$ & 0.0024 & ** & $* * *$ & $* * *$ & $* * *$ \\
\hline
\end{tabular}

Note: significant at: ${ }^{*}-10 \% ;^{* *}-5 \%{ }^{* * *}-1 \%$.

Table 7. Significance of cumulative average abnormal return estimated on the basis of the market model with MSCI World index

\begin{tabular}{|c|c|c|c|c|c|}
\hline$t$ & CAAR & $t$-test & Patell & Boehmer Kolari & GenSign \\
\hline$[-1 ; 1]$ & -0.0036 & $* * *$ & $* * *$ & $* * *$ & * \\
\hline$[-2 ; 2]$ & -0.0045 & $* * *$ & $* * *$ & $* * *$ & \\
\hline
\end{tabular}

Note: significant at: ${ }^{*}-10 \%{ }^{* *}-5 \%{ }^{* * *}-1 \%$.

Table 8. Significance of cumulative average abnormal return estimated on the basis of the constant mean return model

\begin{tabular}{lllllll}
$t$ & CAAR & t-test & Patell & Boehmer & Kolari & GenSign \\
{$[-1 ; 1]$} & -0.0059 & $* * *$ & $* * *$ & $* * *$ & $* *$ & $* * *$ \\
\hdashline$[-2 ; 2]$ & -0.0059 & $* * *$ & $* * *$ & $* * *$ & & \\
\hdashline & $-0 . * \ldots \ldots$
\end{tabular}

Note: significant at: ${ }^{*}-10 \%{ }^{* *}-5 \% ;{ }^{* *}-1 \%$.

Figure 1. The cumulative average abnormal return calculated on the basis of the market model with the MICEX index (micex), market model with the MSCI World index (msci) and the constant mean return model (mean)

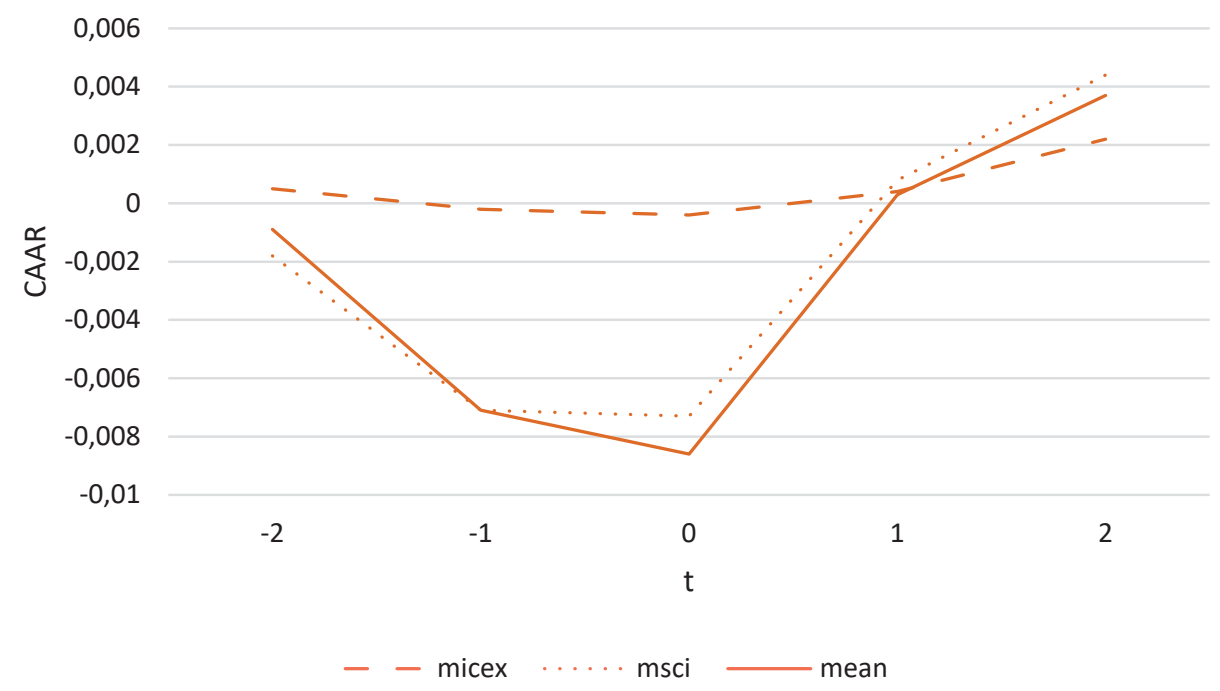

The cumulative average abnormal return for the market model (table 6 ) in the interval of $[-1 ; 1]$ is negative while analyzing a wider window the tests show a significant positive response. Such multidirectionality may be indicative of an increase in the shares' price volatility or of the shares' price reverse reaction after the fall at the day of releasing information on imposition of sanctions.

An analysis of the cumulative average abnormal return for the market model on the basis of a global index and constant mean return model shows a significant negative response at a three-days' event window $[-1 ; 1]$, however at a wider, five-days' event window [-2;2] non-parametric tests show that on average the response was undistinguishable from zero (tables 7-8). This may be explained by heterogeneity of companies as well as by a reverse reaction of prices on the second day after the announcement release.

Fig. 1 shows the dynamics of the cumulative average abnormal return for each of the three analyzed models. The graphical analysis confirms the assumption that use of the model on the basis of a local stock market index results in underestimation of the response of the shares' price to the event. 
Further, we conducted a regression analysis to reveal dependence of the shares' prices response to the features of the sanction and company. In order to check the robustness of the results, we used abnormal returns as the dependent variable for each of three normal returns models. Apart from that, for each dependent variable we tested two models: 1) model with company fixed individual effects; 2) model with industry fixed effects.

The results of estimation of the regression models are presented in table 9. In general, one should point out the robustness of the results with respect to the key determinants of the shares' prices reaction. The constant term is not statistically significant, but it may be related to homogeneity within the sample. As far as sanctioner country is concerned, the strongest shares' price reaction was observed to be related to those sanctions imposed by USA. At the same time, joint sanctions imposed by the USA and EU produced a smaller negative effect than those that were imposed individually by the USA or EU. The results also show that the strength of investors' reaction to imposition of sanctions depended on the company characteristics. Thus, shares of the companies with a higher financial leverage lost ground much more than others. With increase of the financial leverage by one standard deviation the average daily abnormal return within the period of sanction announcement is reduced by $0.5 \%$ points. Industry effects turned out to be individually insignificant. As for the individual effects of companies, on average the least sensitivity to imposition of sanctions was shown by such companies as Sberbank, VTB, Dixi Group and MTS.

Table 9. Analysis of determinants of cumulative abnormal return CAR $[-1 ; 1]$

\begin{tabular}{|c|c|c|c|c|c|c|}
\hline & (1) & $(2)$ & (3) & $(4)$ & (5) & (6) \\
\hline & CAR micex & CAR micex & CAR msci & CAR msci & CAR mean & CAR mean \\
\hline \multirow{2}{*}{$\begin{array}{l}\text { Sanction targeted against a } \\
\text { company }\end{array}$} & -0.004 & -0.003 & -0.006 & -0.003 & -0.003 & -0.001 \\
\hline & $(0.004)$ & $(0.004)$ & $(0.007)$ & $(0.007)$ & $(0.008)$ & $(0.008)$ \\
\hline \multirow{2}{*}{ Sanctions imposed by USA } & $-0.005^{\star *}$ & $-0.005^{\star *}$ & $-0.008^{\star * *}$ & $-0.008^{\star * \star}$ & $-0.009^{* * *}$ & $-0.009^{\star * *}$ \\
\hline & $(0.002)$ & $(0.002)$ & $(0.003)$ & $(0.003)$ & $(0.003)$ & $(0.003)$ \\
\hline \multirow{2}{*}{$\begin{array}{l}\text { Sanctions imposed by EU and } \\
\text { USA simultaneously }\end{array}$} & 0.002 & 0.002 & $0.010^{\star *}$ & $0.010^{\star *}$ & $0.009^{\star *}$ & $0.009^{\star *}$ \\
\hline & $(0.003)$ & $(0.004)$ & $(0.004)$ & $(0.004)$ & $(0.004)$ & $(0.004)$ \\
\hline \multirow{2}{*}{ Financial leverage } & $-0.002^{* * *}$ & $-0.001^{\star}$ & $-0.002^{\star *}$ & -0.001 & $-0.003^{* * *}$ & -0.001 \\
\hline & $(0.001)$ & $(0.001)$ & $(0.001)$ & $(0.001)$ & $(0.001)$ & $(0.001)$ \\
\hline \multirow{2}{*}{ Company size } & & 0.000 & & 0.000 & & 0.000 \\
\hline & & $(0.001)$ & & $(0.002)$ & & $(0.002)$ \\
\hline \multirow{2}{*}{ State ownership } & & -0.000 & & -0.000 & & 0.001 \\
\hline & & $(0.003)$ & & $(0.004)$ & & $(0.004)$ \\
\hline \multirow{2}{*}{2015 year effect } & 0.001 & 0.001 & 0.001 & 0.000 & 0.000 & 0.000 \\
\hline & $(0.002)$ & $(0.002)$ & $(0.003)$ & $(0.003)$ & $(0.003)$ & $(0.003)$ \\
\hline \multirow{2}{*}{2016 year effect } & 0.000 & -0.000 & $0.011^{\star * *}$ & $0.010^{* * *}$ & $0.011^{* * *}$ & $0.010^{\star * *}$ \\
\hline & $(0.002)$ & $(0.002)$ & $(0.003)$ & $(0.003)$ & $(0.003)$ & $(0.003)$ \\
\hline Company effects & Included & & Included & & Included & \\
\hline Industry effects & & Included & & Included & & Included \\
\hline \multirow{2}{*}{ Constant } & -0.006 & 0.004 & -0.016 & -0.003 & -0.019 & -0.007 \\
\hline & $(0.010)$ & $(0.027)$ & $(0.013)$ & $(0.034)$ & $(0.012)$ & $(0.033)$ \\
\hline Number of observations & 1,565 & 1,565 & 1,485 & 1,485 & 1,565 & 1,565 \\
\hline R-squared & 0.025 & 0.007 & 0.025 & 0.011 & 0.026 & 0.013 \\
\hline
\end{tabular}

Note: significant at: ${ }^{*}-10 \% ;{ }^{* *}-5 \% ;{ }^{* *}-1 \%$. Bootstrap standard errors in parentheses. 
Among companies' features that can drive stock market reaction to the announcements related to sanctions, the significant influence of a company's financial leverage was confirmed. However, the model reveals significance of distinguished features of sanctions content as well. An interesting result is a stronger negative investors' reaction to sanctions imposed by USA in comparison to EU sanctions and effect of joint USA and EU sanctions in spite of a large volume of external turnover of Russia with EU countries. As for the period of sanctions in 2016 the investors' negative reaction to prolongation of sanctions turned out to be weaker in comparison to the sanctions imposed in 2014 and 2015. Apart from that, we could not confirm a stronger effect of targeted sanctions in comparison to general sanctions. The relevant effect, as categorized according to industry sector and state ownership turned out to be insignificant.

\section{Conclusions}

Within this research study we analyzed the way Russian stock market investors responded to announcements related to imposition and prolongation of sanctions against Russia because of the conflict with Ukraine. Using the event study method we estimated the influence of sanctions on public companies which shares are included in the MICEX index.

The results showed that the announcements about imposition of sanctions against Russia, on average, negatively influences the Russian companies' shares' prices. This result is in line with the theoretical assumptions behind sanctions and the results of previous empirical studies, for example, by Hoffmann and Neuenkirch [2017]. However, a range of other hypotheses were not confirmed. First, it was found that investors reacted negatively to sanctions imposed by the USA to a greater extent in comparison to the European Union sanctions. This contradicts the assumptions of a stronger influence of sanctions imposed by the countries with which more close trade and economic relations had been established [Jing, Kaempfer, Lowenberg, 2003; Pape, 1997]. But this result may be caused by the fact that the USA initiated the imposition of sanctions. It may be the case that their sanctions preceded sanctions of other countries, and for this reason this turned out to be unexpected news of a more negative import for Russian investors. Also, the assumption of previous studies that sanctions should do a lasting damage to large companies which are more involved in international trade [Golikova, Kuznetsov, 2017] was not confirmed. Probably, such a result is caused by the fact that large companies have more financial resources and opportunities for diversification, thus making it possible for them to reorient to the domestic market. Inasmuch as a series of sanctions targeted the financial sector then it was expected that financially dependent companies were exposed to influence of sanctions to a greater extent.

Although this research does not unambiguously answer the question as to which companies will suffer more losses from sanctions imposed against Russia in the long term and which ones will be able to avail of the opportunity for growth due to the decrease in competition, it does show how stock market investors evaluate such prospects. In future it may be possible to conduct an analysis using a longer time interval as well as to study the process of import substitution in Russian enterprises using data of particular companies. Apart from that, further analysis of the sanctions impact may be conducted with reference to retaliatory measures of Russia and government actions for support of domestic companies. Also, the analysis revealed a series of methodological issues of event study for the analysis of macroeconomic events that influence the country's economy and the stock market in general.

\section{References}

1. Akindinova N.V., Yasin E.G. A new stage of economic development in post-Soviet Russia. Voprosy ekonomiki. 2015;(5):5-27. (In Russ.).

2. Guseva D.E., Rogova E.M. Evaluation of the reaction of the prices of shares of Russian companies to information on investing in innovative projects. Innovatsii $=$ Innovations. 2016;(3):104-112. (In Russ.).

3. Kozhanov N.A. Economic sanctions against Iran: Objectives, scope, possible consequences of the introduction. Moscow: Institute of the Middle East; 2011. 267 p. (In Russ.).

4. Naidenova Yu.N. Disclosure of information on research and development by Russian pharmaceutical companies. Korporativnye finansy $=$ Journal of Corporate Finance Research. 2015;9(2):100-113. (In Russ.).

5. Nureev R.M., Petrakov P.K. The ordinary consumer: The burden of economic sanctions against Russia. Journal of Economic Regulation. 2015;6(3):40-60. DOI 10.17835/2078-5429.2015.6.3.040-060 (In Russ.).

6. Pogozheva A.A. Event study analysis application for testing of the information value of analysts' recommendations on Russian public companies. Korporativnye finansy $=$ Journal of Corporate Finance Research. 2013;7(2):32-45. (In Russ.).

7. Portanskii A.P. Sanctions against Russia - destructive and counterproductive measures. Den'gi i kredit $=$ Russian Journal of Money and Finance. 2014;(10):8-10. (In Russ.).

8. Teplova T.V. Impact of cash dividend payments on Russian companies' market capitalization: Event study testing on Russian and world stock exchange. Audit i finansovyi analiz. 2008;(2):1-15. URL: https://www.hse. ru/data/2010/03/04/1235849408/2008_Teplova_T_ Dividends_and_market_reaction.pdf (In Russ.).

9. Fomicheva M. Economic sanctions in the competition. Vestnik universiteta (Gosudarstvennyi universitet upravleniya). 2016;(7-8):107-111. (In Russ.). 
10. Yavorskaya A.V. Evaluation of cross-listing influence on the market value of Russian companies. Korporativnye finansy = Journal of Corporate Finance Research. 2013;7(3):50-59. (In Russ.).

11. Yavorskaya A.V., Yavorskii V.M. The method of event analysis on the example of cross-listing data of Russian companies. Vesti vysshikh uchebnykh zavedenii Chernozem'ya. 2015;(1):95-105. (In Russ.).

12. Amuzegar J. Iran's economy and the US sanctions. The Middle East Journal. 1997;51(2):185-199.

13. Binder J. The event study methodology since 1969. Review of Quantitative Finance and Accounting. 1998;11(2):111-137. URL: https://www.researchgate.net/ publication/5157403_The_Event_Study_Methodology_ Since_1969

14. Boehmer E., Masumeci J., Poulsen A.B. Event-study methodology under conditions of event-induced variance. Journal of Financial Economics. 1991;30(2):253-272. DOI: 10.1016/0304-405X(91)90032-F

15. Carswell R. Economic sanctions and the Iran experience. Foreign Affairs. 1981;60(2):247-265. DOI $10.2307 / 20041079$

16. Collins S.D. Dissuading state support of terrorism: Strikes or sanctions? (An analysis of dissuasion measures employed against Libya). Studies in Conflict \& Terrorism. 2004;27(1):1-18. DOI: 10.1080/10576100490262115

17. Corrado C.J. A nonparametric test for abnormal security-price performance in event studies. Journal of Financial Economics. 1989;23(2):385-395. DOI: 10.1016/0304-405X(89)90064-0

18. Corrado C.J., Zivney T.L. The specification and power of the sign test in event study hypothesis tests using daily stock returns. The Journal of Financial and Quantitative Analysis. 1992;27(3):465-478. DOI: 10.2307/2331331

19. Cowan A.R. Nonparametric event study tests. Review of Quantitative Finance and Accounting. 1992;2(4):343358. DOI: 10.1007/BF00939016

20. Davis L., Engerman S. History lessons:

Sanctions - neither war nor peace. The Journal of Economic Perspectives. 2003;17(2):187-197. DOI: $10.1257 / 089533003765888502$

21. Esfandiary D., Fitzpatrick M. Sanctions on Iran: Defining and enabling 'success'. Survival: Global Politics and Strategy. 2011;53(5):143-156. DOI 10.1080/00396338.2011.621639

22. Fayazmanesh S. The politics of the US economic sanctions against Iran. Review of Radical Political Economics. 2003;35(3):221-240. DOI $10.1177 / 0486613403254535$

23. Ghanem D., Rosvall D. Major world events impact on stock market prices: An event study. Uppsala: Department of Business Studies, Uppsala University; 2014. 43 p. URL: http://www.diva-portal.org/smash/get/diva2:727314/ FULLTEXT01.pdf

24. Gibbons E., Garfield R. The impact of economic sanctions on health and human rights in Haiti, 1991-1994. American Journal of Public Health. 1999;89(10):14991504. DOI: 10.2105/AJPH.89.10.1499

25. Giumelli F., Ivan P. The effectiveness of EU sanctions: An analysis of Iran, Belarus, Syria and Myanmar (Burma). European Policy Centre. EPC Issue Paper. 2013;(76). URL: http://www.epc.eu/documents/uploads/pub_3928_epc_ issue_paper_76_-_the_effectiveness_of_eu_sanctions.pdf

26. Golikova V., Kuznetsov B. Perception of risks associated with economic sanctions: The case of Russian manufacturing. Post-Soviet Affairs. 2017;33(1):49-62. DOI 10.1080/1060586X.2016.1195094

27. Guidolin M., La Ferrara E. The economic effects of violent conflict: Evidence from asset market reactions. Journal of Peace Research. 2010;47(6):671-684. DOI: $10.1177 / 0022343310381853$

28. Gurvich E., Prilepskiy I. The impact of financial sanctions on the Russian economy. Russian Journal of Economics. 2015;1(4):359-385. DOI 10.1016/j. ruje.2016.02.002

29. Hoffmann M., Neuenkirch M. The pro-Russian conflict and its impact on stock returns in Russia and the Ukraine. International Economics and Economic Policy. 2017;14(1):61-73. DOI: 10.1007/s10368-015-0321-3

30. Hufbauer G.C., Schott J.J., Elliott K.A. Economic sanctions reconsidered: History and current policy. Washington, DC: Peter G. Peterson Institute for International Economics; 1990. 248 p.

31. Jing C., Kaempfer W.H., Lowenberg A.D. Instrument choice and the effectiveness of international sanctions: A simultaneous equations approach. Journal of Peace Research. 2003;40(5):519-535. DOI: $10.1177 / 00223433030405002$

32. Kaempfer W.H., Lowenberg A.D. The political economy of economic sanctions. In: Handbook of defense economics. Vol. 2: Defense in a globalized world. Amsterdam: North-Holland; 2007:867-911.

33. Kaspereit T. EVENTSTUDY2: Stata module to perform event studies with complex test statistics. Statistical Software Components. Boston College Department of Economics. 2016. URL: http://fmwww. bc.edu/repec/bocode/e/eventstudy2.ado

34. Klinova M., Sidorova E. Economic sanctions and their impact on Russian economic relations with the European Union. Problems of Economic Transition. 2016;58(3):218234. DOI 10.1080/10611991.2016.1200391

35. Kolari J.W., Pynnönen S. Event study testing with cross-sectional correlation of abnormal returns. The Review of Financial Studies. 2010;23(11):3996-4025. DOI: $10.1093 /$ rfs/hhq072 
36. Konchitchki Y., O’Leary D.E. Event study methodologies in information systems research. International Journal of Accounting Information Systems. 2011;12(2):99-115. DOI 10.1016/j.accinf.2011.01.002

37. Kozhanov N.A. US economic sanctions against Iran: Undermined by external factors. Middle East Policy. 2011;18(3):144-160. DOI 10.1111/j.14754967.2011.00504.x

38. MacKinlay A.C. Event studies in economics and finance. Journal of Economic Literature. 1997;35(1):13-39. URL: http://blog.uny.ac.id/sukirno/files/2011/09/eventstudy-in-economics-and-finance.pdf

39. O'Sullivan M.L. Iran and the great sanctions debate. The Washington Quarterly. 2010;33(4):7-21. DOI 10.1080/0163660X.2010.516638

40. Pape R.A. Why economic sanctions do not work. International Security. 1997;22(2):90-136.

41. Pape R.A. Why economic sanctions still do not work. International Security. 1998;23(1):66-77. DOI 10.1162/ isec.23.1.66

42. Patell J.M. Corporate forecasts of earnings per share and stock price behavior: Empirical test. Journal of Accounting Research. 1976;14(2):246-276. DOI: $10.2307 / 2490543$

43. Patterson R. EU sanctions on Iran: the European political context. Middle East Policy. 2013;20(1):135-146. DOI 10.1111/mepo.12010

44. Torbat A.E. Impacts of the US trade and financial sanctions on Iran. The World Economy. 2005;28(3):407434. DOI 10.1111/j.1467-9701.2005.00671.x

45. Veebel V., Markus R. Lessons from the EU-Russia sanctions 2014-2015. Baltic Journal of Law \& Politics. 2015;8(1):165-194. DOI 10.1515/bjlp-2015-0015

\section{Appendix}

\section{List of Announcements about Sanctions}

March 1, 2014 - John Kerry threatened Russia with sanctions.

March 4, 2014 - the US Congress develops a draft law on sanctions against Russia, military and investment cooperation is suspended.

March 13, 2014 - USA will impose sanctions on Russia if a referendum in Crimea takes place.

March 16, 2014 - imposition of sanctions against a series of Russian officials (freezing of bank accounts, arrest of property, visa denials).

March 17, 2014 - imposition of sanctions against 21 politicians and officials (ban on entry to the EU, freezing of money and economic resources).
March 20, 2014 - the list of individual persons against whom sanctions are imposed is extended; sanctions are imposed on the bank named 'Rossiya'.

March 21, 2014 - the list of individual persons against whom sanctions are imposed is extended.

March 27, 2014 - suspension of cooperation with Russia, suspension of export of "potentially unsafe products".

April 2, 2014 - suspension of cooperation with Russia (law-enforcement agencies, antiballistic missile defense, space sphere).

April 7, 2014 - access to facilities of the Ministry of Energy is restricted.

April 17, 2014 - EU urges to elect not to build the gas pipeline project named 'South Stream'.

April 28, 2014 - the list of individual persons and companies against which sanctions are imposed is extended; USA declares a prohibition on sale of hightechnology goods into Russia.

May 7, 2014 - removal of Russia from the trading program of duty-free import of certain types of goods into USA.

May 12, 2014 - the list of persons against whom sanctions are imposed is extended; sanctions are imposed on Chernomorneftegaz and Feodosiya.

June 18, 2014 - the list of companies against which sanctions are imposed is extended (Fryazino Branch of the Institute of Radio Engineering and Electronics of the Russian Academy of Sciences, OJSC Voyentelecom, Academy of Business Security, Ampika Pumps LLC, Nuklin LLC).

June 21, 2014 - the list of persons against whom sanctions are imposed is extended.

July 12, 2014 - the list of persons against whom sanctions are imposed is extended.

July 16, 2014 - the list of individual persons and companies against which sanctions are imposed is extended (Rosneft, Novatek, Vnesheconombank, Gazprombank, Almaz-Antey Corporation, Izhmash of Kalashnikov Concern, JSC Research and Production Association Bazalt, Uralvagonzavod and Instrument Design Bureau, NPO Mashinostroyeniya, RadioElectronic Technologies Concern, Sozvezdiye, Fedodosiya Neftebaza).

July 25, 2014 - refusal to support projects of the World Bank in Russia.

July 26, 2014 - extension of the sanctions list for 15 persons and 18 organizations.

July 29, 2014 - the list of companies against which sanctions are imposed is extended (Bank of Moscow, Bank VTB and Rosselkhozbank; United Shipbuilding Corporation). 
July 31, 2014 - EU extends the list of companies against which sanctions are imposed (Sberbank of Russia, Bank VTB, Gazprombank, Vnesheconombank, Rosselkhozbank); ban on providing Russia with hightechnology equipment for oil extraction in the Arctic Region, at the deep marine shelf and light tight oil.

August 6, 2014 - ban on providing equipment for deepsea extraction, exploitation of the Arctic shelf and shale oil and gas reserves, on providing unconventional energy carriers extraction technologies: drilling rigs, horizontal directional drilling parts, subsea equipment, sea equipment for operation in the Arctic Region, software for formation hydraulic fracturing, remotely operated underwater vehicles, high-pressure pumps.

September 12, 2014 - the list of companies against which sanctions are imposed is extended (Gazprom, Lukoil, Transneft, Gazprom Neft, Surgutneftegas, Novatek, Rosneft, Sberbank, Bank of Moscow, Gazprombank, Rosselkhozbank, Vnesheconombank, Bank VTB, Rostekh, Concern Military and Political Research Center AlmazAntey, PJSC Dolgoprudny Research and Development Enterprise, PJSC M.I.Kalinin Machine-Building Plant, PJSC Mytishchi Machine-Building Plant, PJSC V.V. Tikhomirov Scientific Research Institute of Instrument Design).

September 25, 2014 - the Overseas Private Investment Corporation suspends consideration of any investments in Russian projects.

December 19, 2014 - imposition of economic sanctions against Crimea; the list of Russian individual persons against whom sanctions are imposed is extended.

March 4, 2015 - prolongation of restrictive measures against Russia for a year.
March 11, 2015 - the list of Russian individual persons against whom sanctions are imposed is extended.

March 13, 2015 - EU prolongs sanctions against individual persons and legal entities.

June 22, 2015 - EU prolongs sanctions against Russia.

June 24, 2015 - From now on USA may punish foreign banks for cooperation with clients listed in the sanctions list.

July 30, 2015 - the list of individual persons and organizations against which sanctions are imposed is extended.

August 7, 2015 - sanctions are imposed against YuzhnoKirinskoe Field of Sakhalin-3 Project of Gazprom Company.

December 21, 2015 - EU prolongs sanctions against Russia.

December 22, 2015 - the list of individual persons and organizations against which sanctions are imposed is extended.

March 2, 2016 - sanctions against Russia are prolonged for a year.

March 10, 2016 - EU prolongs sanctions against legal entities and individual persons.

September 1,2016 - the list of individual persons and organizations against which sanctions are imposed is extended.

September 6, 2016 - the list of companies against which sanctions are imposed is extended.

September 16, 2016 - EU prolongs individual sanctions against Russia. 